\title{
Menelaah Living Qur'an-Hadis Akad Jual Beli Pada Masyarakat Kuala Tungkal Kabupaten Tanjung Jabung Barat Propinsi Jambi
}

\author{
Ulya Fuhaidah $^{1}$
}

\begin{abstract}
Sighat akad of selling and buying is recommended by al-Shafii. In the daily practice of trading, it can be found easily in Kuala Tungkal, Tanjung Jabung Barat Jambi. This research tries to explore the tradition through phenomenology. The data are gathered by observation and interview. The result is the practice of reciting sighat akad can be taced as living Quran and Hadits. To some extend it is influenced by Qadiriyah and Naqsabandiyah tradition.
\end{abstract}

\begin{abstract}
Abstrak
Pelafalan akad jual beli dengan lisan secara jahr penulis temukan sangat marak dipraktekkan di pasar tradisional maupun warungwarung dan segala macam transaksi jual beli yang ada di wilayah Kuala Tungkal Kabupaten Tanjung Jabung Barat Propinsi Jambi. Praktek ini terutama dilakukan oleh generasi tua. Praktek yang sama hampir tidak penulis temukan di Kabupaten lain di wilayah Propinsi Jambi kecuali pelakunya orang dari Kuala Tungkal. Oleh karena itu, riset ini akan mengeksplorasi tentang living QuranHadis akad jual beli pada masyarakat Kuala Tungkal dengan menggunakan pendekatan fenomenologi. Pengumpulan data diperoleh melalui tahapan yakni observasi dan wawancara. Hasil riset menemukan bahwa living Quran-Hadis tersebut dipengaruhi oleh tradisi keagamaan yang kuat di kalangan masyarakat di mana mayoritas adalah pengamal ajaran tarekat Qadiriyah Naqsabandiyah.
\end{abstract}

Keywords: living Quran-Hadis, akad, jual-beli, Kuala Tungkal

\section{Pendahuluan}

Fazlur Rahman (w.1988) membagi para pengkaji al-Qur'an menjadi tiga kelompok besar yang dianalogikan seperti sebuah negara. Kelompok pertama adalah citizens, di mana maksudnya adalah penduduk asli yakni dari kalangan

1 Dosen Fakultas Syari'ah UIN Sultan Thaha Saifuddin Jambi. E-mail: Ulya0882@gmail.com 
internal umat Islam dan kelompok kedua dinamakan foreigners yang memiliki makna kelompok asing atau non-muslim yang mempelajari al-Qur'an. Sementara kelompok ketiga adalah invader di mana kelompok ini adalah para penjajah yang akan menghancurkan al-Qur' an. ${ }^{2}$

Berbeda dengan kategori Fazlur Rahman di atas, Farid Esack dalam karyanya The Qur'an: a Short Introduction membagi pengkaji al-Qur'an seperti interaksi antara seorang pencinta dan yang dicinta. Kelompok pertama disebut uncritical lover (pencinta yang tidak kritis) yang terdiri dari tiga golongan yakni orang-orang awam (ordinary muslim), para sarjana konvensional (scholarly lover), dan pencinta yang kritis (critical lover). Sedangkan kelompok kedua disebut dengan golongan the friends of lover yang juga terbagi menjadi tiga golongan. Perbedaan antara kelompok pertama dan kedua adalah berdasarkan keyakinan dan kepercayaan, karena pada kelompok ini dihuni oleh para nonmuslim pengkaji al-Qur' an yang disebut outsider, revisionist, dan polemics. ${ }^{3}$

Berikut ini adalah penjabaran definisi kelompok-kelompok tersebut di atas menurut Farid Esack. Orang awam adalah muslim yang berinteraksi dengan al-Qur'an secara buta tanpa mempertanyakan dan meragukan tentang al-Qur'an karena kitab suci ini adalah segala-galanya. Sarjana muslim adalah mereka para pencinta al-Qur'an yang berusaha menjelaskan kemukjizatan al-Qur'an secara ilmiah. Ulama dalam kelompok ini misalnya Abu al-a'la Maududi dalam karyanya Tafhìm al-Qur'ān, Amin Ahsan Islahi dengan Tadabbur al-Qur'ān, Husain Țabațaba'i dengan al-Mizan fî Tafsìr al-Qur'ān, Aisyah Abdur Rahman (Bint Syati) dengan Tafsīir al Bayān Iì al-Qur'ān al-Karìm, Abū al-Qasìm alKhū'i dengan al-Bayān fì Tafsīr al-Qur'ān, dan masih banyak lagi sarjana muslim lainnya. Sementara critical lover adalah pencinta yang sangat kritis seperti Fazlur Rahman, Muhammad Arkoun, dan Nasr Hamid Abū Zayd. ${ }^{4}$

Pemetaan kelompok kedua pada umumnya ditempati oleh kalangan orientalis dengan kadar kebencian yang rendah terhadap al-Qur'an sampai pada tingkatan yang menolak al-Quran sacara membabi buta. The outsider misalnya dinisbahkan kepada para orientalis seperti Cenneth Cragg dengan karyanya The Event of al-Qur'an, William Montgomery Watt dengan karyanya Companion to The Qur'an, William Graham dengan karyanya Divine Word and Prophetic World in Early Islam. Pada tingkat kedua, kelompok Revisionist adalah mereka yang ingin mengubah dan melemahkan al-Quran dengan bukti-bukti akademis.

${ }^{2}$ Hamam Faizin, "Mencium dan Nyunggi al-Qur'an: Upaya Pengembangan Kajian al-Qur'an Melalui Living Qur'an”, Jurnal Suhuf, 4, 1, (2011): 25.

${ }^{3}$ Faizin, "Mencium dan Nyunggi al-Qur'an", 27.

${ }^{4}$ Faizin, "Mencium dan Nyunggi al-Qur'an", 26. 
Contoh orientalis pada kelompok ini adalah Patricia Crone dan Michael Cook. Kelompok ketiga, polemics adalah mereka non-muslim yang menolak kebenaran al-Qur'an. ${ }^{5}$ Demikianlah pembagian para pengkaji al-Qur'an sebagai khazanah bagaimana manusia berinteraksi dengan kitab suci ini.

Kajian tentang Qur'an-Hadis kontemporer tidak lagi memfokuskan pada ilmu-ilmu tentang Qur'an dan Hadis tetapi telah menyentuh aspek sosial dari kedua sumber utama pedoman hidup umat Islam. Dengan demikian living Qur'an dan Hadis adalah bagian dari kajian lived religion, practical religion, popular religion, lived Islam, yang bertujuan menggali bagaimana manusia dan masyarakat memahami dan menjalankan agama mereka, untuk tidak mengutamakan kaum elit agama (pemikir, otoritas agama, pengkhotbah, dan sebagainya) memonopoli kajian kedua sumber tersebut. Metode-metode saintifik sosial memasuki wilayah kajian agama dan para sarjana beralih dari kajian naskah kepada kajian masyarakat beriman pada masa kini (present-day living communities of faith). ${ }^{6}$

Ditinjau dari sisi linguistik, kata Living Qur'an terdiri dari dua suku kata yang berbeda, living diartikan dengan hidup dan kata Qur'an merupakan wahyu terakhir yang tertulis dalam mushaf. Dengan bahasa sederhana, Living Qur'an dapat diartikan dengan teks ayat al-Qur'an yang hidup di tengah masyarakat. Oleh karena itu kajian Living Qur'an mengandung makna menjadikan ayat alQur'an sebagai teks yang hidup, bukan teks yang mati. Dalam kaitan ini, fokus pembahasan Living Qur'an ini adalah ayat-ayat yang berkembang atau telah membumi di tengah masyarakat. Adapun perdebatan seputar otentisitas alQur'an, perbedaan metode, kaidah, corak penafsiran tidak terlalu dirisaukan dalam kajian ini. Penelitian lebih fokus pada peran praktis al-Qur'an dalam sikap, aktivitas individu atau masyarakat umum, serta membahas pemahaman sekelompok masyarakat terhadap ayat al-Qur'an bukan penafsiran ayat alQur'an. ${ }^{8}$

Dalam kaitannya dengan tulisan ini, Living Qur'an adalah kajian atau penelitian ilmiah tentang berbagai peristiwa sosial terkait dengan kehadiran al-

\footnotetext{
${ }^{5}$ Faizin, "Mencium dan Nyunggi al-Qur'an", 27.

${ }^{6}$ Muhammad Ali, "Kajian Naskah dan Kajian Living Qur'an dan Living Hadith", Journal of Qur'an and Hadith Studies 4, 2, (2015): 147-167.

7 Sahiron Syamsuddin, "Ranah-ranah Penelitian dalam Studi al-Qur'an dan Hadis," dalam Sahiron Syamsuddin (ed.), Metode Penelitian Living Qur'an dan Hadis (Yogyakarta: Teras, 2007), xiv

${ }^{8}$ Syahrul Rahman, "Living Qur'an: Studi Kasus Pembacaan al-Ma'tsurat di Pesantren Khalid Bin Walid Pasir Pengaraian Kab. Rokan Hulu", Jurnal Syahadah, IV, 2( 2016): 60 .
} 
Qur'an atau keberadaan al-Qur'an di sebuah komunitas muslim tertentu. ${ }^{9}$ Ditinjau dari aspek historis, sebenarnya praktek memperlakukan al-Qur'an (surat-surat atau ayat-ayat tertentu di dalam al-Qur'an) untuk kehidupan praksis umat, sudah terjadi sejak masa Rasulullah SAW. Dalam rekaman sejarah, Nabi Muhammad SAW dan para sahabat pernah melakukan praktek ruqyah, yaitu mengobati dirinya sendiri dan juga orang lain yang menderita sakit dengan membacakan ayat-ayat tertentu di dalam al-Qur'an. ${ }^{10}$ Dikisahkan oleh Aisyah bahwa Nabi Muhammad SAW pernah membaca surat al-Mu'awwidhatain, yaitu surat al-Falaq dan al-Naas ketika beliau sedang sakit sebelum wafatnya. Sementara dalam riwayat lain disebutkan, bahwa sahabat Nabi pernah mengobati seseorang yang tersengat hewan berbisa dengan membaca al-Fatihah. Dari beberapa keterangan riwayat hadis di atas, menunjukkan bahwa praktek interaksi umat Islam dengan al-Qur'an, tidak sebatas pada pemahaman teks semata, tetapi sudah menyentuh aspek yang sama sekali di luar teks.

Membahas interaksi al-Qur'an dengan masyarakat, terdapat fenomena yang menarik pada masyarakat Kuala Tungkal di Kabupaten Tanjung Jabung Barat Propinsi Jambi. Mereka memiliki tradisi melafalkan secara jahr akad jual beli antara penjual dan pembeli sebagaimana berikut: "Aku beli ye", kata si pembeli. Ucapan pembeli ini langsung dijawab oleh si penjual "ye, aku jual". Akad jual beli dalam logat Melayu tersebut pasti diucapkan oleh kedua belah pihak yang melakukan transaksi jual beli. Kalimat inilah yang penulis dengar ketika berbelanja di pasar tradisional di wilayah Kota Kuala Tungkal. Berdasarkan observasi, ternyata mayoritas masyarakat mempraktekkan hal ini pada seluruh aktivitas jual beli baik di pasar tradisional maupun di warungwarung kelontong. Fenomena ini tentu saja menjadi sesuatu yang baru karena penulis bukan penduduk asli dari Kuala Tungkal dan belum menemukan praktek yang sama di daerah manapun, sekalipun di Kabupaten lainnya di Propinsi Jambi. Pada umumnya orang beranggapan bahwa jual beli itu sudah sah ketika pembeli menyerahkan uang sebagai bayaran atas apa yang dibelinya tanpa harus mengucapkan akad jual beli secara lugas dan jahr.

Melalui fenomena ini, maka penulis tertarik untuk mengkaji tentang tradisi melafalkan akad jual beli secara lisan di kalangan masyarakat Kuala Tungkal. Untuk mengelaborasi fenomena ini secara komprehensif penulis merasa perlu juga untuk memaparkan tentang bagaimana tipologi dan

\footnotetext{
${ }^{9}$ M. Mansur, "Living Qur'an dalam Lintasan Sejarah Studi Al-Qur'an,” dalam Sahiron Syamsuddin (ed.), Metode Penelitian Living Qur'an dan Hadis, 8

${ }_{10}$ Didi Junaedi. "Living Qur'an : Sebuah Pendekatan Baru dalam Kajian AlQur' an”, Journal of Qur'an and Hadith Studies 4, 2, (2015): 174
} 
kehidupan keagamaan masyarakat Kuala Tungkal agar terjawab apa yang melandasi tradisi melafalkan jual beli di kalangan mereka.

Terkait dengan metode penelitian, riset ini adalah riset lapangan yang menggunakan pendekatan fenomenologi, di mana penulis ingin mengetahui lebih dalam tentang makna di balik sebuah peristiwa dengan cara menggambarkan peristiwa yang terjadi secara apa adanya. ${ }^{11}$ Adapun data yang terkumpul diperoleh melalui observasi dan wawancara kepada kelompok masyarakat tertentu.

\section{Tipologi dan Keagamaan Masyarakat Kuala Tungkal}

Tanjung Jabung Barat adalah sebuah kabupaten yang terletak di pantai Timur Propinsi Jambi dengan ibu kota Kuala Tungkal. Berdasarkan letak geografisnya, Kabupaten ini berbatasan dengan Kabupaten Inderagiri Ilir Propinsi Riau di sebelah utara, Kabupaten Muaro Jambi di sebelah selatan, Kabupaten Tanjung Jabung Timur di sebelah timur, dan Kabupaten Batanghari dan Tebo di sebelah barat. ${ }^{12}$

Sebelum dilakukan pemekaran, wilayah administrasi Tanjung Jabung Barat tergabung dengan Tanjung Jabung Timur. Namun berdasarkan Perda Nomor 8 Tahun 2008 kemudian terjadi pemekaran sehingga menjadi wilayah administrasi sendiri dengan jumlah kecamatan menjadi 13 kecamat an meliputi Tungkal Ulu, Merlung, Batang Asam, Tebing Tinggi, Renah Mendaluh, Muara Papalik, Pengabuan, Senyerang, Tungkal Ilir, Bram Itam, Seberang Kota, Betara, dan Kuala Betara ${ }^{13}$.

Berdasarkan data statistik, mayoritas masyarakat Kuala Tungkal adalah penganut agama Islam dengan jumlah lebih dari $95 \%$ pada tahun 2015 dan berasal dari suku yang beragam seperti Banjar, Bugis, Batak, Jawa, Minang, Melayu, India, dan lain-lain. ${ }^{14}$ Masyarakat Kuala Tungkal dikenal sebagai masyarakat yang religius. Hal ini ditunjukkan oleh maraknya berbagai kegiatan keagamaan di Kuala Tungkal berupa pengajian masyarakat bahkan sampai festival keagamaan seperti lomba arakan sahur dan festival beduk yang diperlombakan untuk menyambut Hari Raya Idul Fitri dan Idul Adha. ${ }^{15}$

${ }^{11}$ Heddy Shri Ahimsa-Putra, "Fenomenologi Agama: Pendekatan Fenomenologi Untuk Memahami Agama", Jurnal Walisongo: Jurnal Penelitian Sosial Keagamaan, 20, 2, (2012): 300 .

${ }^{12} \mathrm{http}: / /$ jambi.bps.go.id/linkTabelStatis/view/id/540.

${ }^{13}$ (RPJP, 2015).

${ }^{14} \mathrm{http} / / / j a m b i . b p s . g o . i d / l i n k T a b l e D i n a m i s / v i e w / i d / 223$.

${ }^{15} \mathrm{https}$ ://rakyatjambi.co/arakan-sahur-jadi-tradisi-masyarakat-kuala-tungkal/. 
Di wilayah Kuala Tungkal ini juga berdiri beberapa pondok pesantren. Pesantren yang terbesar adalah al-Baqiyatus Shalihat yang berlokasi di Parit Gompong Kuala Tungkal Jambi. Pesantren ini memiliki majelis ta'lim dan jamiyyah tarekat dengan jumlah ribuan pengikut. KH. Muhammad Ali Abdul Wahhab (1934-2011) adalah salah satu pengasuh Pondok Pesantren al Baqiyatush Sholihat dan tokoh ulama terkemuka di Kuala Tungkal. Sebelumnya, beliau adalah salah satu pengajar di Perguruan Hidayatul Islamiah (PHI), madrasah embrio pesantren al-Baqiyat. Beliaulah yang memperkenalkan ajaran Tarekat Qadiriyah Naqsabandiyah di wilayah Jambi.

Secara geneologis, beliau merupakan keturunan Syekh Arsyad alBanjari. Beliau merupakan putra pertama dari empat bersaudara dari pasangan Tuan Guru Abdul Wahab bin Tuan guru H. Ismail bin Tuan guru H.M Thohir bin Tuan guru H. Syahabuddin (1880-1964) dan Hj. Ruqayyah yang berasal dari Batu Pahat Johor. ${ }^{16}$

Pada masa kanak-kanak, KH Muhammad Ali Abdul Wahhab berkesempatan tinggal di Makkah al-Mukaramah pada kurun 1937-1939. Kemudian ketika kembali ke Kuala Tungkal melanjutkan pendidikan di Madrasah Ibtidaiyah al-Istiqamah yang diselesaikannya pada tahun 1943. Kemudian pendidikan menengahnya ditempuh di Madrasah HidayatuI Islamiyah, Kuala Tungkal pada kurun 1950-1953. Pada tahun yang sama juga menimba ilmu di Madrasah Nurul Falah Kuala Tungkal (1950-1953). Selanjutnya beliau melanjutkan pendidikan di Pondok Pesantren al-As'ad Jambi (1953-1956) dan di Madrasah Ad-Diniyyatul Islamiyah Brabai Kalimantan Selatan (1956 1958). ${ }^{17}$

Sekembalinya dari pesantren, beliau aktif terlibat dalam aktivitas keagamaan di lingkungan sekitar sebagaimana terangkum dalam penjelasan berikut ini:

Tahun 1950-an, mendirikan Tarbiyatul Mubalighin di Kuala Tungkal.

Tahun 1962, mendirikan Tarbiyatud da' wah wal Mudzakaroh di Kuala Tungkal. Tahun 1979, mendirikan Tarekat Qodiriyah Naqsabandiyah di Kuala Tungkal. Tahun 1979, sebagai pendiri Majlis Ta'lim al-Hidayah di Kuala Tungkal.

Tahun 1992, sebagai anggota Mahkamah Syari'ah (Pengadilan Agama Kuala Tungkal) dan menjabat sebagai ketua Fatwa Majelis Ulama Kuala Tungkal.

\footnotetext{
${ }^{16}$ Ulya Fuhaidah. "Tarekat and Philantrophy". Paper disampaikan pada the $2^{\text {nd }}$ Studia Islamika International Conference UIN Syarif Hidayatullah Jakarta 2017.

${ }^{17}$ Fuhaidah, Tarekat, 12.
} 
Tahun 1994, mendirikan Pondok Pesantren al-Baqiyatush Sholihat Kuala Tungkal. ${ }^{18}$

Silsilah Tarekat Qadiriyah Naqsabandiyah yang diperkenalkan oleh beliau diambil dari jalur Syeikh Nawawi Berjan Purworejo Jawa Tengah. Syeikh Nawawi adalah mursyid generasi ketiga dalam tarekat ini. Beliau dibaiat menjadi mursyid menggantikan ayahandanya Kiai Siddiq yang wafat pada 1948. Kiai Siddiq sendiri mempelajari tarekat ini melalui ayahnya Syeikh Zarkasyi (1830-1917) yang langsung mendapat ijazah dari Syeikh Abdul Karim Banten sebagai khalifah pasca wafatnya Syeikh Ahmad Khatib Sambas. ${ }^{19}$

Aktivitas utama para pengamal tarekat ini adalah zikir dan pengajian. Pada awalnya aktifitas pengajian tarekat diselenggarakan di rumah $\mathrm{KH}$ Muhammad Ali Abdul Wahhab, namun lambat laun tempat tinggalnya itu tidak mampu menampung jamaah yang hadir sehingga pengajian dipindahkan ke Masjid Agung al-Istiqamah yang berada persis di depan rumah beliau. Peristiwa ini terjadi pada kurun 1985. Jamaah yang hadir tidak hanya murid tarekat tetapi juga masyarakat awam yang ingin menimba ilmu keagamaan.

Masjid Agung al-Istiqamah kemudian menjadi pusat pengajian keagamaan. Adapun kitab yang dibacakan saat pengajian antara lain Sair alSalikin karya 'Abd al-Samad al-Palimbani pada pengajian senin malam, Hidayah al-Salikin, dan Fath 'Arifin karya Syekh Muhammad Sarni bin Muhammad Sidiq al-Allaby pada pengajian pagi selasa. Sementara pada pengajian jum'ah pagi, para jamaah kembali mendengarkan pembacaan kitab Hidayah Salikin. Beberapa kitab tersebut adalah kitab tasawuf dan fiqh. ${ }^{20}$ Dari kegiatan pengajian tersebut dapat dipahami bahwa setiap 3 hari dalam sepekan diselenggarakan pengajian dan zikir tarekat Qadiriyah Naqsabandiyah.

Berikut ini akan diuraikan tentang kitab yang dibacakan pada kajian di masjid Agung al-Istiqamah. Kitab pertama adalah Hidayah al-Salikin merupakan karya monumental Abd al-Samad al-Palimbani yang ditulis pada kurun 1871 M. Kitab ini judul panjangnya Hidāyah al-Sālikīn fi Sulūk Maslak al-Muttaqqīn (Pedoman Bagi Orang yang Berjalan Pada Perjalanan Orang yang Takut Akan Allah Ta'ala) atau judul ringkasnya Hidāyah al-Sālikīn merupakan salah satu kitab terawal yang ditulis oleh beliau. Dalam kitab ini dicatat bahwa

18 Wahyudi Abdul Wahab, "Tipologi Gerakan Ulama Kuala Tungkal di Era Reformasi", Journal Kontekstualita, 27, (2012): 77.

19 Amelia Fauzia. Faith And The State: A History of Islamic Philanthropy in Indonesia. Books.google.com. 2013:123.

20 Syaidah, "Wacana Keagamaan Dalam Pengajian di Masjid Agung AlIstiqamah Kuala Tungkal Untuk Membentuk Masyarakat Islami”, Innovasio: Journal for Religious and Innovation Studies, 14, 2, (2014): 5. 
selesai ditulis pada hari Selasa, 5 Muharam tahun 1192 H di Mekah. Selain judul tersebut, judul lain yang diberikan kepada kitab ini disebut Bidāyah alSälikīn. Namun manuskrip yang menggunakan judul Bidāyah al-Sālikīn sangat langka dibanding judul Hidāyah al-Sālikīn yang lebih banyak ditemui. Judul Bidāyah al-Sālikīn hanya didapati pada manuskrip yang dicetak dalam bentuk cetakan huruf litografi, yang diterbitkan di Singapura sekitar tahun 1287H/1870M. Manuskrip dengan judul ini terdapat dalam koleksi manuskrip Muzium Islam di Pusat Islam, Kuala Lumpur, dengan nomor kelas MI 170, MI 277 dan MI 334. ${ }^{21}$

Mengenai kandungan kitab Hidāyah al-Sālikīn mencakup pembahasan tiga bidang pengajian Islam, yaitu akidah, fiqih dan tasawuf. Walaupun kitab ini dikenal sebagai kitab tasawuf, namun struktur kandungan kitab tersebut menunjukkan juga pembahasan bidang akidah dan fiqih. Ilmu akidah dibincangkan dalam bab pertama dengan judul "Pada Menyatakan Akidah Ahli Ahl al-Sunnah wa al-Jamā'ah." Adapun permasalahan fiqh terkandung dalam bab kedua dengan judul "Pada Menyatakan Berbuat Taat dan Ibadah yang Zahir," yang menguraikan ketaatan melalui amalan ibadah harian. Sementara lima bab selebihnya yang sejak bab ketiga hingga ketujuh, khusus membahas permasalahan ilmu tasawuf. Pokok pembahasan lima bab terakhir tersebut meliputi permasalahan hati, penyakit hati, sifat perhiasan bagi hati, zikrullah, adab-adab berhubungan sesama manusia dan adab hubungan dengan Allah SWT. Oleh karena itu menjadikan kitab ini sebagai kitab tasawuf karena bab ini pembahasannya diuraikan lebih detail pada kitab tersebut. ${ }^{22}$ Kitab ini menjadi kitab penting di dunia Melayu Islam sampai saat ini.

Kitab kajian yang kedua yakni kitab Sair al-Sâlikîn. Judul lengkapnya adalah Sira al-Sâlikîn fi Thariqah as-Sâdât ash-Shûfîyah. Dalam penerbitan lain lebih banyak menyebutkan judul lengkap kitab ini dengan Sair as-Sâlikîn ila Ibadah Rabb al-Alamin. Kitab ini merupakan kitab tasawuf dalam bahasa Arab Melayu yang terdiri atas empat bagian. Bagian pertama membahas tentang ilmu ushuluddin dan segala masalah yang berkaitan dengan ibadah zahir (ditulis pada 1193 H/1779 M dan selesai pada awal tahun 1194 H/1780 M di Mekah). Bagian kedua membahas hukum dan adab yang berlaku dalam kehidupan (mulai ditulis pada 1194 H/1780 M dan selesai pada hari Sabtu, 19 Ramadan 1195 H/1781 M di Thaif). Bagian ketiga membahas maksiat yang membinasakan amal (mulai ditulis pada tahun 1195 H/1781 M dan diselesaikan pada 19 Safar 1197 H/1783

${ }^{21}$ Shohana Hussin, "Kitab Hidāyah al-Sālikīn Karangan al-Falimbān̄̄: Analisis Naskhah dan Kandungan”, Jurnal Usuluddin (Januari - Jun 2014) 39:71-109.

${ }^{22}$ Hussin,"Kitab Hidayah", 105. 
M di Mekkah). Bagian keempat membahas ibadah batin (tidak disebutkan tahun penulisannya, sedangkan selesainya pada 20 Ramadan 1203 H/1788 M di Thaif). Sebagian besar isi kitab ini adalah merupakan terjemahan dari Lubab Ihya (mukhtasar atau ringkasan kitab Ihya Ulumiddin karya al-Ghazali). Penulisnya, Abd al-Samad sendiri menggolongkan kitab ini sebagai kitab tasawuf mubtadi (pemula). ${ }^{23}$

Adapun kitab ketiga adalah Fath al-Arifin. Kitab ini merupakan terjemahan dari kitab Hikam karya Syaikh Abu Al-Fadhli Ahmad ibn Muhamad Abd Al-Karim ibn 'Atha'illah Al-Sakandary (w. 709 H).7 Kitab al-Arifin membicarakan tentang jalan orang yang arif billah dan ahli tauhid yang meningkat di maqam yang tinggi yaitu mengetahui bagaimana pengenalan mereka kepada Tuhan dan pendidikan yang mereka berikan kepada para pengikutnya. $^{24}$

Berkaitan dengan para tokoh ulama di Kuala Tungkal, terdapat juga beberapa ulama kharismatik lainnya di kota ini selain KH Muhammad Ali yang juga berperan penting menghidupkan syiar Islam. Ulama-ulama tersebut antara lain: Kyai Ahmadi, Kyai Fuad Damhuzi, KH Hasan Basri, KH Iskandar Akbar, KH Fathul Arifin, Kyai Khairuddin, dan Kyai Mahyudin Arif. ${ }^{25}$ Beberapa di antara mereka juga menyelenggarakan pengajian di kediaman masing-masing yang jadwalnya tidak sama dengan agenda pengajian yang diselenggarakan di masjid al-Istiqomah pada senin malam, pagi selasa, dan jum'at pagi.

Dari kondisi keagamaan masyarakat Kuala Tungkal di atas, maka dapat dipahami jika masyarakat di kota ini sangat Islami. Hal ini dapat dengan mudah dilihat dengan ditandai ramainya masjid, madrasah, dan rumah ulama ketika berlangsung pengajian harian maupun mingguan. Adapun pengajian yang menjadi event tahunan adalah pengajian peringatan wafatnya (haul) Syekh Abdul Qadir al-Jilany yang diperingati setiap tanggal 11 Rabiul Akhir menurut kalender Hijriyah. Pada event ini masyarakat dan pemerintah daerah Kuala Tungkal bekerjasama menyelenggarakannya di Pondok Pesantren al Baqiyatus Shalihat yang terletak di Parit Gompong Kuala Tungkal. Pada perayaan haul ini dihadiri para ulama, pejabat, dan para undangan. Jamaah yang hadir diperkirakan lebih dari dua puluh ribu orang yang berasal tidak hanya dari

${ }^{23}$ Rodiah, "Insan Kamil dalam Pemikiran Muhammad Nafis al-Banjari dan Abdush Shamad al-Falimbani dalam Kitab Ad-Durr an-Nafis dan Siyar as-Salikin", Jurnal Studia Insania, 3, 2,(2015): 102.

${ }^{24}$ Syaidah, "Wacana Keagamaan", 6.

${ }^{25}$ Wahyudi. Tipologi Gerakan Ulama, 78. 
Kuala Tungkal tetapi juga dari luar negeri yakni Malaysia, Singapura, dan Brunei Darussalam. ${ }^{26}$

\section{Living Qur'an-Hadis Akad Jual Beli}

Secara etimologi, jual beli artinya menukar harta dengan harta. Adapun secara terminologis ia berarti transaksi penukaran selain dengan fasilitas dan kenikmatan sebagaimana pernikahan dan persewaan. ${ }^{27}$ Menurut pengertian syariat, jual beli adalah pertukaran harta atas dasar saling rela atau memindahkan milik dengan cara yang dibenarkan. ${ }^{28}$ Definisi yang disebutkan oleh Syekh al-Qalyubi bahwa akad saling mengganti dengan harta yang berakibat pada kepemilikan terhadap satu benda atau manfaat untuk tempo waktu selamanya dan bukan untuk bertaqarrub ila Alah. Dengan kata lain hibah tidak termasuk di dalamnya karena tidak ada saling mengganti walaupun memiliki tujuan taqarub kepada Allah. ${ }^{29}$

Merujuk definisi di atas maka jual beli dapat dilakukan dengan dua cara yakni pertukaran harta antara dua pihak atas dasar saling rela dan memindahkan milik dengan ganti yang dapat dibenarkan yaitu berupa alat tukar yang diakui sah dalam perdagangan. Dengan demikian, proses pemindahan kepemilikan yang dilakukan dengan cara paksaan dan cara yang batil bukanlah jual beli. Hukum asal jual beli adalah mubah. ${ }^{30}$ Jual beli merupakan praktek yang sudah lama dilakukan manusia untuk memenuhi kebutuhan ekonominya. Setiap zaman memiliki ciri dan caranya masing-masing mulai dari jual beli yang paling sederhana yakni pertukaran barang, pertukaran mata uang, hingga pertukaran saham, dan bahkan jual beli secara online di era kontemporer.

Dalam Islam, jual beli dianggap sebagai salah satu sumber utama rezki bagi ummat Islam sebagaimana hadis dari Ruf'ah bin Rafi menurut al-Bazar yang disahkan oleh al-Hakim sebagai berikut:

$26 \mathrm{http} / /$ lintastungkal.com/puluhan-ribu-jamaah-hadiri-haul-syekh-abdul-kadirjailani-di-kuala-tungkal-2/

${ }^{27}$ Abdullah al-Muslih dan Shalah as-Shawi. Fiqh Ekonomi Keuangan Islam. Terj. Abu Umar Basyir. (Jakarta: Darul Haq, 2004), 87.

${ }^{28}$ Suhrawardi K. Lubis dan Farid Wajdi. Hukum Ekonomi Islam. Jakarta: Sinar Grafika, 2014, 139.

${ }^{29}$ Abdul Aziz Muhammd Azam, Fiqh Muamalah: Sistem Transaksi dalam Fiqh Islam (Jakarta: Bumi Aksara, 2014), 24.

30 Yudhistira ANM Massardi (ed). Ensiklopedi Leadership dan Manajemen Muhammad SAW: The Super Leadership, Super Manajemen (Jakarta: Tazkia Publishing, 2010), 122 . 


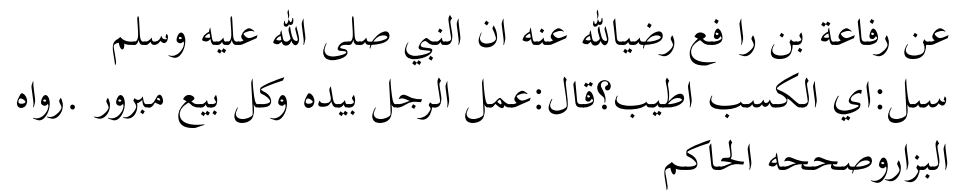

Artinya: Sesungguhnya Nabi Muhammad $S A W$ pernah ditanya tentang usaha apa yang paling baik, Nabi berkata usaha seseorang dengan tangannya dan jual beli yang mabrur. ${ }^{31}$

Hadis tersebut dapat ditemukan pula pada musnad Imam Ahmad nomor 16628 dengan redaksi yang berbeda di bawah ini:

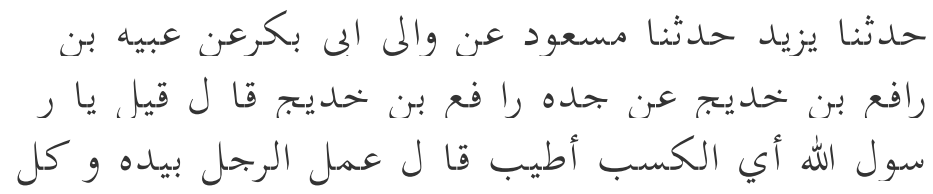

بيع مبرور

Artinya: Telah menceritakan kepada kami [Yazid] telah menceritakan kepada kami [Al Mas'udi] dari [Wail Abu Bakr] dari [Abayah bin Rifa'ah bin Rafi' bin Khadij] dari kakeknya [Rafi' bin Khadij] dia berkata, "Dikatakan, "Wahai Rasulullah, mata pencaharian apakah yang paling baik?" beliau bersabda: "Pekerjaan seorang laki-laki dengan tangannya sendiri dan setiap jual beli yang mabrur." 32

Konsep mabrur tidak hanya berkaitan dengan ibadah haji tetapi juga pada transaksi jual beli. Mabrur dalam konteks ini diartikan dengan jual beli yang tidak ada khianat dan dusta di dalamnya. Perilaku dusta seperti menyembunyikan aib barang dari penglihatan pembeli. Sementara maksud khianat adalah menyamarkan bentuk barang yang dijual dengan sifat yang tidak benar. Dengan demikian jual beli mabrur adalah perniagaan yang penuh kebaikan sehingga diberkahi oleh Allah SWT.

Dalam kitab suci Al Qur'an, menjelaskan bahwa Allah SWT membolehkan jual beli dan mengharamkan riba sebagaimana yang tersurat dalam QS al-Baqarah ayat 275 berikut ini:

31 Nur Akhmad Zaroni, "Bisnis Dalam Perspektif Islam (Telaah Aspek Keagamaan dalam Kehidupan Ekonomi)”, Mazahib: Jurnal Pemikiran Hukum Islam, 4, 2 , (2007).

${ }^{32}$ https://tafsirq.com/hadits/ahmad/16628. 


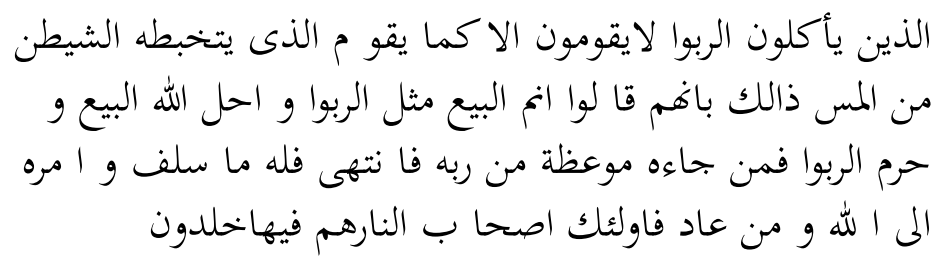

Artinya: Padahal Allah telah menghalalkan jual beli dan mengharamkan riba. Siapa yang mendapat peringatan Tuhannya lalu ia berhenti melakukan riba, maka apa yang telah diperolehnya dahulu menjadi miliknya dan urusan diserahkan kepada Allah. Orang yang mengulangi perbuatan riba akan menjadi penghuni neraka. Mereka kekal di dalamnya. ${ }^{33}$

Beberapa hal yang dijelaskan pada ayat tersebut adalah pertama, transaksi jual beli tidak sama dengan riba. Kedua, perdagangan itu dibolehkan, sedangkan riba itu diharamkan. Ketiga, mereka yang mendengar ayat larangan riba harus berhenti mempraktekannya tanpa mengembalikan riba yang telah ditarik. $^{34}$ Pengharaman riba pada ayat di atas disebabkan karena riba mengandung unsur gharar (penipuan) dan spekulasi (maisir), maupun karena mengandung unsur kecurangan (tathfif) dan perilaku lainnya yang merugikan orang lain. Pada intinya pengharaman riba untuk menghentikan eksploitasi baik dalam jumlah banyak maupun sedikit.

Ayat-ayat tentang keharaman riba ada yang dipisahkan dengan ayat jual beli, tetapi di sisi yang lain terdapat juga ayat yang menyatukan antara jual beli dan riba. Proses pengharaman riba dalam al-Qur'an dilakukan secara bertahap sekitar empat sampai lima tahapan yakni pada tahap awal diturunkan Surah alRum: 39, Surah al-Nisa ayat 160-161, Surah Ali Imran ayat 130, dan kemudian Surah al-Baqarah ayat 275-281. ${ }^{35}$

Dasar dalil al-Qur'an selanjutnya tentang ayat perniagaan adalah Surah an-Nisa 29-31:

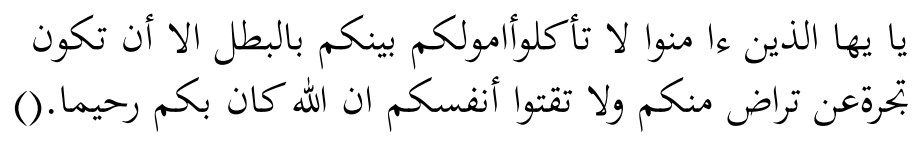

${ }^{33}$ Muhammad Syafii Antonio, Bank Syariah Dari Teori ke Praktek (Jakarta: Gema Insani, 2001:48).

${ }^{34}$ M. Dawam Raharjo. Ensiklopedi al-Qur'an: Tafsir Sosial Berdasarkan KonsepKonsep Kunci (Jakarta: Paramadina, 2002), 605.

${ }^{35}$ Muhammad Amin Suma, Tafsir Ayat Ekonomi: Teks, Terjemah, Tafsir (Jakarta: Amzah, 2005), 155. 


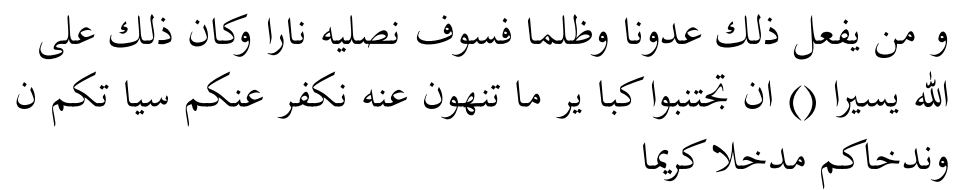

Artinya: hai orang-orang yang beriman, janganlah kamu saling memakan harta sesama kamu dengan cara yang batil kecuali dengan cara perniagaan yang dilakukan dengan asas rela sama rela di antara kamu, dan janganlah kamu kamu membunuh dirimu sendiri karena sesungguhnya Allah itu maha penyayang kepadamu. Dan siapa yang berbuat demikian dengan permusuhan (melanggar hak dan aniaya), maka kelak Kami akan memasukkannya ke dalam neraka. Yang demikian itu adalah mudah bagi Allah. Jika kamu menjauhi dosa-dosa besar di antara dosa-dosa yang kamu dilarang mengerjakannya, maka niscaya kami akan hapus kesalahan-kesalahan (dosa-dosamu yang kecil), dan Kami akan masukkan kamu ke tempat yang mulia.

Penjelasan ayat di atas pada dasarnya mengharamkan orang-orang beriman melakukan usaha dan menikmati keuntungannya dengan cara-cara yang batil. Penggunaan kata al-akl mengisyaratkan kata makan yang umum digunakan masyarakat untuk maksud bekerja atau usaha. Sedangkan redaksi bainakum (di antara kamu) mengisyaratkan bahwa harta kekayaan pada umumnya diperoleh melalui perantaraan transaksi ekonomi yang melibatkan alākil (pemakan) dan al-ma'kul (yang dimakan). Adapun yang dimaksud dengan cara batil adalah cara yang diharamkan seperti riba, penipuan, perjudian, dan lain-lain. Oleh karena itu, usaha yang diperbolehkan adalah jual beli yang dihalalkan atas dasar suka rela. ${ }^{36}$

Dalil selanjutnya yang yang dirujuk sebagai dasar jual beli adalah ayat terakhir Surah al-Baqarah 282 tentang persaksian jual beli: ${ }^{37}$

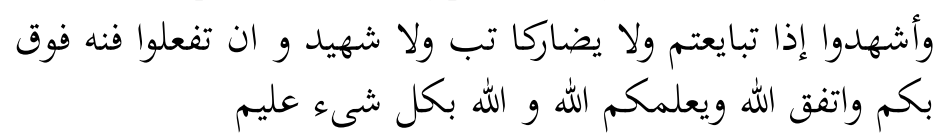

Artinya: Dan persaksikanlah apabila kamu berjual beli; dan janganlah penulis dan saksi saling sulit-menyulitkan. Jika kamu lakukan (yang demikian), maka sesungguhnya hal itu adalah suatu kefasikan pada dirimu. Dan bertakwalah kepada Allah; Allah mengajarmu; dan Allah Maha Mengetahui segala sesuatu.

\footnotetext{
${ }^{36}$ Amin Suma, Tafsir Ayat Ekonomi, 160.

${ }^{37}$ Siti Mujiatun.”Jual Beli Dalam Perspektif Islam: Salam dan Istisna”, Jurnal Riset Akuntansi dan Bisnis, 13, 2 (2013), 204.
} 
Jual beli dalam Islam diuraikan secara detail dalam ilmu fiqh. Secara etimologi, fiqh berasal dari kata faqiha yang berarti paham. Terdapat perbedaan di kalangan ulama terkait pembagian hukum Islam di dalamnya. Ulama Hanafi berpendapat bahwa pokok-pokok urusan agama adalah akidah, akhlak, ibadah, muamalah, dan jinayah. Sementara ulama Mazhab Syafi'i membagi hukum Islam menjadi empat bidang yakni ibadah, muamalah, munakahat, dan 'uqūbah (hukuman). Walaupun berbeda pendapat tentang klasifikasi hukum Islam, tetapi mereka sepakat bahwa pembagian pokoknya adalah masalah ibadah dan muamalah. $^{38}$

Fiqh Muamalah dalam fiqh kontemporer adalah peraturan yang menaungi tentang jual beli karena merupakan aspek hidup yang mengatur hubungan antar individu dengan individu. Cabang-cabangnya kemudian dikaji secara detail oleh para ulama fiqh meliputi seluruh aspek jual beli termasuk halhal yang dapat merugikan kedua belah pihak baik penjual maupun pembeli. Maka untuk melindungi hak-hak antar individu, hukum jual beli secara rinci dalam Islam menjadi kajian para ulama fiqh baik ulama salaf maupun ulama khalaf. Disebutkan dalam literature fiqh bahwa jual beli haruslah memenuhi syarat baik subjeknya, objeknya, dan tentang lafalnya. Berkaitan dengan subjek, kedua belah pihak yang melakukan transaksi harus berakal dan baligh, bukan karena paksaan, dan keduanya tidak mubazir. Tentang objeknya, harus memenuhi syarat yaitu bersih barangnya (suci), dapat dimanfaatkan, milik orang yang melakukan akad, mampu menyerahkannya, mengetahui, dan barang yang diakadkan dikuasainya. ${ }^{39}$

Para ulama pada umumnya membagi rukun jual beli meliputi lima hal yakni: penjual, pembeli, barang yang dijual, kalimat transaksi (ijab dan qabul), dan keridhaan di antara kedua belah pihak. Keridhaan antara dua pihak ini tersurat dalam Al-Qur' an pada surah An-Nisa ayat 29:

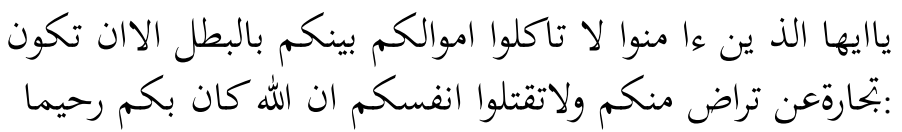

Artinya: "Hai orang yang beriman, janganlah kamu memakan harta sesamamu dengan cara yang haram kecuali dalam perdagangan yang berlaku atas dasar suka sama suka di antara kamu. Janganlah kamu membunuh dirimu. Sesungguhnya Allah maha penyayang di antaramu".

\footnotetext{
${ }^{38}$ Ensiklopedi Hukum Islam (Jakarta: PT Ichtiar Baru Van Hoeve, 1996), 356.

39 Suhrawardi, Hukum Ekonomi, 143.
} 
Jika merujuk pada hadis, unsur keridhaan ini dapat ditemukan pula pada hadis Nabi Muhammad yang diriwayatkan oleh Ibnu Majah berikut ini: ${ }^{40}$

\section{انما البيع عن تراض \\ Artinya: "jual beli itu dianggap sah hanyalah berdasarkan keridhaan".}

Berdasarkan hadis di atas, maka kerelaan menjadi syarat penting sahnya transaksi jual beli antara kedua belah pihak. Artinya tidak ada pihak yang merasa terpaksa. Kerelaan bersifat batiniah, maka harus dimanifestasikan dengan ucapan sebagai tanda sahnya jual beli. Ketika penulis wawancara kepada para informan, umumnya mereka tidak menyadari secara sepenuhnya dan detail bahwa praktek mengucapkan sighat jual beli pada masyarakat Kuala Tungkal itu bersumber dari ajaran agama utamanya al-Qur'an dan hadis. Dasar dalil al-Qur' an yang dimaksud adalah QS Al-Maidah ayat 1

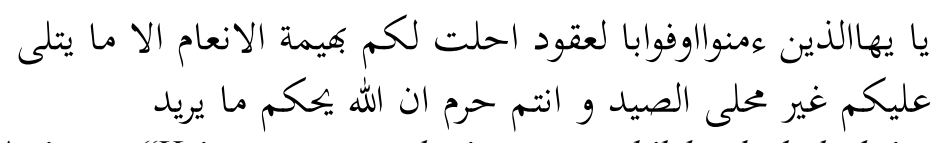

Artinya: "Hai orang yang beriman, penuhilah akad-akad itu. Dihalalkan bagimu binatang ternak, kecuali yang akan dibacakan kepadamu. Yang demikian itu dengan tidak menghalalkan berburu ketika kamu sedang mengerjakan haji. Sesungguhnya Allah menetapkan hukum-hukum menurut yang dikehendaki".

Dalam tafsir Quraish Shihab, dijelaskan bahwa surah ini termasuk dalam kelompok Madaniyah dan merupakan surat yang terakhir kali turun. Kata aqd itu sendiri mengandung arti penguatan, pengukuhan. Uqud (jamak aqd) yang digunakan dalam ayat ini pada dasarnya berlangsung antara dua belah pihak. Dengan demikian dapat dipahami bahwa al-Qur'an telah berbicara tentang pemenuhan janji di antara dua pihak yang melakukan perjanjian.

Adapun dasar dalil tentang jual beli dari hadis adalah sebagaimana hadis Nasai Nomor 4396 yang artinya sebagai berikut:

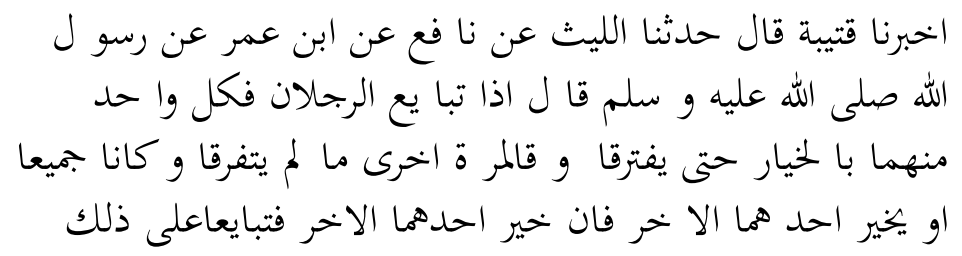

${ }^{40}$ Abu Bakar Jabir al-Jazairi, Minhajul Muslim. Alih Bahasa Mustafa 'Aini dkk. (Medan: IAIN Sumatera Utara, 2014), 799. 


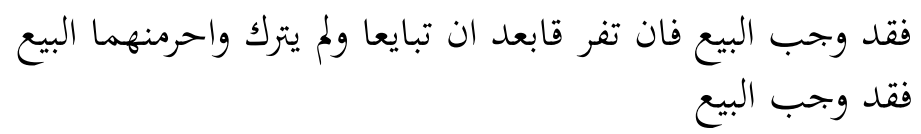

Artinya: "Telah mengabarkan kepada kami Qutaibah. Ia berkata telah menceritakan kepada kami Al-Laits dan Nafi dari Ibnu Umar dari Rasulallah bersabda: apabila dua orang saling berjual beli maka setiap mereka memiliki hak memilih hingga mereka berpisah dan berkata sekali lagi. Selama mereka belum berpisah, atau salah seorang di antara mereka memberikan hak memilih kepada yang lain, maka apabila salah seorang di antara mereka memberikan hak memilih kepada yang lain kemudian mereka berjual beli atas dasar hal tersebut, maka jual beli mereka telah tetap. Kemudian apabila mereka berpisah setelah melakukan jual beli dan salah seorang di antara mereka tidak meninggalkan jual beli, maka jual beli tersebut tetaplah tetap".

Melihat realitas praktek jual beli di pasar dan warung-warung pada masyarakat Kota Kuala Tungkal, penulis kemudian memiliki asumsi bahwa secara tidak langsung pengajian yang berlangsung di masjid al-Istiqamah membawa dampak positif terhadap perilaku keagamaan masyarakat Kuala Tungkal. Namun berdasarkan observasi penulis, perilaku religius ini mayoritas dipraktekkan oleh kalangan tua. Mengapa terjadi demikian? Karena anak muda pada umumnya kurang tertarik mengikuti pengajian-pengajian yang diselenggarakan di rumah para tuan guru maupun di masjid.

Observasi partisipatif oleh penulis di atas kemudian diperkuat dengan data wawancara. Sebagaimana wawancara penulis dengan salah sat u masyarakat setempat. $\mathrm{Hj}$. Masnah mengungkapkan bahwa ia terbiasa melafalkan akad jual beli. Ia menilai bahwa jual beli itu akan sah dan sempurna jika akad sudah terucapkan dengan jelas. Ia menambahkan bahwa lafal itu boleh diawali oleh pembeli maupun penjual, kendati ia tidak mengetahui dalil dari AlQur'an maupun hadis mana yang dirujuk sebagai pedoman mengamalkan perilaku tersebut. Ia hanya meyakini bahwa kebiasaannya ini juga diajarkan pada pengajian kitab fiqh yang membahas tentang jual beli.

Pendapat $\mathrm{Hj}$. Masnah tersebut senada dengan argumen masyarakat Kuala Tungkal lainnya yang pada umumnya hanya menjawab bahwa melafalkan akad jual beli adalah tuntunan seperti yang disebutkan dalam kitab-kitab kuning. Penulis berasumsi bahwa kitab kuning yang dimaksud adalah kitab-kitab fiqh dan ibadah lainnya yang diajarkan pada pengajian di surau maupun masjid di Kuala Tungkal. 
Jika merujuk pada ilmu fiqh, maka ijab dan qabul antara penjual dan pembeli atau sighatul aqdi yang berarti perkataan yang menunjukkan kepada kehendak kedua belah pihak merupakan salah satu rukun jual beli. Apabila rukun jual beli tidak terpenuhi, maka tidak akan sah transaksi jual beli di antara kedua belah pihak.

Imam Mahalli dan an-Nawawi sangat mendahulukan sighat karena sighat adalah ijab dan qabul. Ijab berasal dari kata aujaba yang artinya meletakkan dari pihak penjual yaitu pemberian hak milik, dan qabul artinya orang yang menerima hak milik. Jika penjual berkata "bi'tuka" yang artinya saya jual kepadamu, maka ini berarti ijab. Jika pihak lain berkata “qabiltu”, maka inilah yang disebut qabul. Jadi di dalam jual beli penjual selalu menjadi yang berijab dan pembeli menjadi penerima baik diawalkan maupun diakhirkan lafalnya. ${ }^{41}$

Para ulama tidak berbeda pendapat tentang keabsahan jual beli yang menggunakan sighat sharih (jelas dan lugas) seperti ucapan "saya jual kepadamu, saya jadikan hak milikmu dan belilah dariku". Perbedaan pendapat terdapat pada pemakaian kata-kata kiasan dalam jual beli (kinayah) karena bisa jadi orang yang diajak berbicara tidak memahami jika sedang berbicara tentang jual beli. Oleh karena itu, sikap berhati-hati penting karena akad jual beli berpengaruh terhadap keabsahannya. Penulis berpendapat bahwa praktek melafalkan akad jual beli pada masyarakat Kuala Tungkal sebagai bagian mewujudkan jual beli yang dilandasi suka rela sesuai dengan syariat Islam.

Berdasarkan referensi kajian fiqh Muamalat, agar ijab dan qabul menghasilkan pengaruh dan akad secara syar'i, maka wajib dipenuhi syaratsyarat sebagai berikut:

1. Qabul harus sesuai dengan ijab

2. Tidak diselingi ucapan yang asing dalam akad

3. Tidak ada jeda diam yang panjang antara ijab dan qabul yang menggambarkan penolakan terhadap qabul

4. Orang yang melakukan ijab dan qabul melafalkan sighat yang dapat didengar oleh orang yang ada di sekitarnya. ${ }^{42}$

Berkaitan dengan syarat sah dan rukun jual beli sebagaimana kajian ilmu fiqh di atas, penulis berupaya mengaitkan dengan fenomena melafalkan akad jual beli secara syarih di masyarakat Kuala Tungkal. Praktek yang dilakukan oleh mereka sejatinya adalah manifestasi dari pengamalan keagamaan seorang muslim. Mereka berupaya menjadi insan kamil yang menjalankan segala perintah agama dan menjauhi segala larangan sebagaimana penjelasan dalam

\footnotetext{
41 Azam, Fiqh Muamalat, 29.

${ }^{42}$ Azam, Fiqh Muamalat, 34.
} 
kitab kajian mereka yakni Siar Salikin dan Hidayah Salikin karya ulama panutan dunia Melayu Abd al-Shamad al-Palimbani.

Masyarakat yang melafalkan akad jual beli secara sharih adalah mereka yang menghidupkan Qur'an dan Hadis di dalam diri mereka sebagaimana termaktub pada QS An-Nisa ayat 29 dan hadis Nabi Muhammad yang menyatakan bahwa salah satu unsur keabsahan perdagangan adalah kerelaan antara penjual dan pembeli. ${ }^{43}$ Kerelaan adalah rasa yang tersimpan di dalam hati, maka perlu dizahirkan dengan sebuah perkataan. Maka lahirlah ucapan dalam logat Melayu "aku jual" sebagai bagian ijab dan "aku beli" sebagai qabul dari pembeli pada transaksi jual beli di kalangan masyarakat Kuala Tungkal.

Praktek yang dilakukan oleh masyarakat tersebut sebagaiman pendapat Imam Malik bin Anas, Abu Hanifah, Abu Yusuf yang menyatakan bahwa makna An-Taradhin Minkum tersebut adalah keridhaan dalam jual beli terletak pada akad, di mana penjual menyerahkan barang dan pembeli menyerahkan uangnya, baik ada khiyar atau tidak setelah atau masih dalam transaksi. Dengan alasan karena jual beli terjadi dengan lisan atau ucapan, maka keridhaan itu bisa dinyatakan dengan ucapan. ${ }^{44}$

Penulis berpendapat bahwa living Qur'an Hadis ini di masa yang akan datang dikhawatirkan akan hilang dipraktekkan oleh masyarakat. Terdapat dua faktor yang berpengaruh terhadap eksistensi tradisi ini. Pertama adalah kelompok pemuda dan yang kedua adalah perkembangan teknologi informasi. Berdasarkan observasi penulis, kalangan pemuda di Kuala Tungkal sedikit yang mengucapkan akad jual beli secara sharih dengan konsisten. Mereka tidak lagi menganggap bahwa sighat adalah bagian dari rukun jual beli yang tidak boleh ditinggalkan. Mereka berpendapat bahwa pembayaran dalam sebuah transaksi adalah sebagai bentuk sahnya transaksi antara penjual dan pembeli walau tanpa terucap ijab qabul. Kondisi ini sangat kontras dengan generasi tua yang pada umumnya juga merupakan murid tarekat Qadiriyah Naqsabandiyah. Mereka sebagian besar dengan konsisten melafalkan sighat jual beli di akhir transaksi sebagai syarat sahnya jual beli.

Faktor kedua berhubungan dengan teknologi informasi. Hal ini terkait dengan kecanggihan internet. Dewasa ini mulai tumbuh dan berkembang pesat perdagangan berbasis online yang dapat dengan mudah diaplikasikan dan diakses di dalam telpon genggam secara personal. Perdagangan online ini

\footnotetext{
${ }^{43} \mathrm{http}: / /$ quran.ksu.edu.sa/tafseer/tabary/sura4-aya29.html

${ }^{44}$ Adiwarman A. Karim, Bank Islam Analisis Fiqih dan Keuangan, (Jakarta:
} Rawali Pers, Cet. VII, 2010), 31. 
menyediakan tidak hanya barang tetapi juga jasa yang terjadi di dunia maya dimana penjual dan pembeli tidak harus bertemu dan berada dalam satu majlis ketika melakukan transaksi jual beli. Dengan demikian tidak akan terdengar sighat jual beli yang diucapkan secara sharih.

\section{Penutup}

Berdasarkan penjelasan di atas penulis menyimpulkan bahwa tradisi melafalkan akad jual beli pada masyarakat Kota Kuala Tungkal terutama oleh generasi tua sejatinya adalah Living Qur'an Hadis yang dipraktekkan oleh masyarakat. Walaupun pada umumnya masyarakat tidak menyadari sepenuhnya bahwa apa yang mereka lakukan adalah bersumber dari dua ajaran pokok agama Islam itu sendiri yakni Qur'an dan Hadis. Pelafalan akad jual beli secara sharih ini sebagai ekspresi persetujuan dan kerelaan antara penjual dan pembeli.

Akan tetapi, praktek ini sekarang mulai terkikis oleh budaya modern, di mana kelompok pemuda sedikit yang mengamalkan pelafalan akad jual beli. Ancaman kedua terhadap living Qur'an Hadis jual beli tersebut datang dari sistem jual beli online, dimana pembeli dan penjual tidak harus bertemu dalam satu majelis. Dari kondisi ini maka tidak akan ada lafal jual beli yang diucapkan oleh kedua belah pihak sebagaimana praktek jual beli pada masyarakat Kuala Tungkal.

Mengeliminir hilangnya tradisi ini dalam kehidupan masyarakat di Tanjung Jabung Barat, maka perlu upaya serius dari orang tua dan institusi pendidikan untuk mengajarkan kepada para pemuda pentingnya melafalkan ijab qabul secara syarih karena hal itu adalah salah satu rukun jual beli. Jika ijab dan qabul tidak dilafalkan, maka berakibat tidak sahnya transaksi antara penjual dan pembeli. Merujuk dalam pendidikan Islam bahwa amal harus didahului oleh ilmu.

\section{Daftar Pustaka}

Ahimsa-Putra, Heddy Shri. Fenomenologi Agama: Pendekatan Fenomenologi Untuk Memahami Agama. Jurnal Walisongo: Jurnal Penelitian Sosial Keagamaan, 20, 2 (2012).

Ahmad Nur, Zaroni. "Bisnis Dalam Perspektif Islam (Telaah Aspek Keagamaan dalam Kehidupan Ekonomi)". Mazahib: Jurnal Pemikiran Hukum Islam, 4, 2, (2007). 
Ali, Muhammad. “Kajian Naskah dan Kajian Living Qur'an dan Living Hadith", Journal of Qur'an and Hadith Studies Vol. 4, No. 2, (2015).

Antonio, Muhammad Syafii. Bank Syariah Dari Teori ke Praktek. Jakarta: Gema Insani, 2001.

Azam, Abdul Aziz Muhammd. Fiqh Muamalah: Sistem Transaksi dalam Fiqh Islam. Jakarta: Bumi Aksara, 2014.

Azim, Said Abdul. Jual Beli. Jakarta: Qishti Press, 2008.

Ensiklopedi Hukum Islam. Jakarta: PT Ichtiar Baru Van Hoeve, 1996.

Faizin, Hamam. "Mencium dan Nyunggi al-Qur'an: Upaya Pengembangan Kajian al-Qur'an Melalui Living Qur'an”, Jurnal Suhuf, 4, 1, (2011).

Fauzia, Amelia. Faith and The State: A History of Islamic Philanthropy in Indonesia. Asian Studies e-Books online. 2013.

Fuhaidah, Ulya. Tarekat and Philantrophy. Paper disampaikan pada the $2^{\text {nd }}$ Studia Islamika International Conference UIN Syarif Hidayatullah Jakarta 2017.

Hama Nuryani, Neneng Nurhasanah, dan Sandy Rizky Febriandi. Analisis Keabsahan Jual Beli Menurut Fiqh Muamalah dan KUH Perdata. Prosiding Keuangan Unisba, 2017.

Hussin, Shohana. "Kitab Hidāyah al-Sālikīn Karangan al-Falimbānī: Analisis Naskhah dan Kandungan" Jurnal Usuluddin (Januari - Jun 2014) 39:71109.

Al-Jazairi, Abu Bakar Jabir. Minhajul Muslim. Terj. Musthofa Aini, dkk. Medan: IAIN USU, 2014.

Junaedi, Didi. "Living Qur'an: Sebuah Pendekatan Baru dalam Kajian alQur'an”, Journal of Qur'an and Hadith Studies 4, 2, (2015).

Karim, Adiwarman A. Bank Islam Analisis Fiqih dan Keuangan. Jakarta: Rawali Pers, Cet. VII, 2010.

Massardi, Yudhistira ANM (ed). Ensiklopedi Leadership dan Manajemen Muhammad SAW: The Super Leadership, Super Manajemen. Jakarta: Tazkia Publishing, 2010.

M. Mansur. "Living Qur'an dalam Lintasan Sejarah Studi al-Qur'an," dalam Sahiron Syamsuddin (ed.). Metode Penelitian Living Qur'an dan Hadis. Yogyakarta: Teras, 2007.

Mujiatun, Siti."Jual Beli Dalam Perspektif Islam: Salam dan Istisna”. Jurnal Riset Akuntansi dan Bisnis, 13, 2 (2013).

al-Muslih, Abdullah dan Shalah as-Shawi. Fiqh Ekonomi Keuangan Islam. Terj. Abu Umar Basyir. Jakarta: Darul Haq, 2004. 
Nor, Sulaiman Mohammad. "Hidāyat al-Sālikīn: Analisa Hadis dalam Mempengaruhi Budaya Melayu Palembang”. Jurnal Ilmu Agama, 17, 1, (2016).

Prabowo, Nurhadi. Model Kepemimpinan Pondok Pesantren Al-Baqiyatush Shalihat Kuala Tungkal. Tesis tidak diterbitkan UIN Sunan Kalijaga Yogyakarta, 2016.

Raharjo. M. Dawam. Ensiklopedi al-Qur'an: Tafsir Sosial Berdasarkan KonsepKonsep Kunci. Jakarta: Paramadina, 2002.

Rahman, Syahrul. 'Living Qur'an: Studi Kasus Pembacaan al-Ma'tsurat di Pesantren Khalid Bin Walid Pasir Pengaraian Kab. Rokan Hulu”. Jurnal Syahadah, IV, 2 Oktober (2016).

Rodiah. "Insan Kamil dalam Pemikiran Muhammad Nafis al-Banjari dan Abdush Shamad al-Falimbani dalam Kitab Al-Durr al-Nāfis dan Siyar alSālikīn”. Studia Insania, 3, 2, (2015).

Romdhon, Muhammad Rizki. Jual Beli Online Menurut Mazhab Syafi'i. Tasikmalaya: Pustaka Cipasung, 2015.

Saleh, Syukri Ahmad. "Kontribusi KH M. Ali Abdul Wahhab Dalam Melestarikan Tradisi Keilmuan Keagamaan Etnis Banjar di Kuala Tungkal Propinsi Jambi”. Konferensi Internasional Transformasi Sosial dan Intelektual Orang Banjar Kontemporer. IAIN Antasari Banjarmasin, 2016.

Syamsuddin, Sahiron. "Ranah-ranah Penelitian dalam Studi al-Qur'an dan Hadis," dalam Sahiron Syamsuddin (ed.). Metode Penelitian Living dan Hadis (Yogyakarta: Teras, 2007).

Syaidah. "Wacana Keagamaan Dalam Pengajian di Masjid Agung Al-Istiqamah

Kuala Tungkal Untuk Membentuk Masyarakat Islami”. Innovasio: Journal for Religious and Innovation Studies, 14, 2, (2014).

Syaifullah. "Etika Jual Beli Dalam Islam”. Hunafa: Jurnal Studi Islamika, 11, 2 , (2014).

Wahab, Wahyudi Abdul. "Tipologi Gerakan Ulama Kuala Tungkal di Era Reformasi”. Jurnal Kontekstualitas IAIN STS (2016).

Yulianti, RT. “Asas-asas Perjanjian (Akad) Dalam Hukum Kontrak Syariah”. La Riba: Jurnal Ekonomi Islam, 2, 1 (2008).

http://jambi.bps.go.id/linkTabelStatis/view/id/540

http://jambi.bps.go.id/linkTableDinamis/view/id/223

https://rakyatjambi.co/arakan-sahur-jadi-tradisi-masyarakat-kuala-tungkal/ http://lintastungkal.com/puluhan-ribu-jamaah-hadiri-haul-syekh-abdul-kadirjailani-di-kuala-tungkal-2/ 
Ulya Fuhaidah

http://quran.ksu.edu.sa/tafseer/tabary/sura4-aya29.html

100 Vol. 5, No. 1, (2016) 